
doi: https://doi.org/10.17509/jlb.v11i1

\title{
Karakteristik Kepemimpinan Sunda dalam Novel Sejarah Mantri Jero Karya R. Memed Sastrahadiprawira
}

\author{
Danan Darajat, Ruhaliah, Retty Isnendes \\ Universitas Pendidikan Indonesia \\ danan.darajat@upi.edu
}

\begin{abstract}
Sejarah Artikel: Diterima (20 Januari 2020); Diperbaiki (27 Februari 2020); Disetujui (15 Maret 2020); Published (30 April 2020)

Bagaimana mengutip artikel ini (dalam gaya APA): Darajat, D., Ruhaliah, Isnendes, R. (2020). Karakteristik Kepemimpinan Sunda dalam Novel Sejarah Mantri Jero Karya R. Memed Sastrahadiprawira. Lokabasa, 11(1), 10-21. doi: https://doi.org/10.17509/jlb.v11i1.25162
\end{abstract}

Abstrak: Penelitian ini dilatarbelakangi oleh adanya anggapan yang menyebutkan bahwa kepemimpinan orang Sunda masih lemah, padahal dalam sejarah dicatat nama-nama pemimpin Sunda yang hebat dan bisa dijadikan contoh untuk yang lainnya, seperti Prabu Wangi, Niskala Wastu Kancana, dan Sri Baduga Maharaja. Demikian juga dalam karya fiksi, salah satunya yaitu tokoh utama dalam novel sejarah Mantri Jero. Penelitian ini bertujuan untuk menganalisis dan mendeskripsikan: 1) struktur cerita novel sejarah Mantri Jero, 2) karakteristik kepemimpinan Sunda dalam novel sejarah Mantri Jero, dan 3) nilai etnopedagogi dalam novel sejarah Mantri Jero karya R. Memed Sastrahadiprawira. Sumber data penelitian ini, yaitu novel sejarah Mantri Jero karya R. Memed Sastrahadiprawira. Metode dan teknik yang dipakai dalam penelitian ini, yaitu metode deskriptif, teknik telaah pustaka, dan studi dokumentasi, sedangkan cara menganalisisnya menggunakan pendekatan kualitatif. Instrumen yang digunakan terbagi dua, yaitu instrumen untuk mengumpulkan data (ceklis buku sumber) dan instrumen untuk mengolah data (kartu data). Hasil penelitian ini menunjukkan bahwa dalam novel sejarah Mantri Jero terdapat karakteristik kepemimpinan Sunda yang ada pada diri Yogaswara selaku tokoh utamanya. Karakter-karakter tersebut yaitu parigeuing, dasa pasanta, pangimbuhning twah, dan opat panyaraman. Dengan begitu dapat disimpulkan bahwa novel sejarah Mantri Jero mempunyai struktur cerita yang lengkap, karakteristik kepemimpinan Sunda yang baik, dan nilai-nilai etnopedagogi yang dikelompokkan dari karakteristik kepemimpinan Sunda yang bagus.

Kata Kunci: etnopedagogi; karakter kepemimpinan; Mantri Jero; struktur

\section{Characteristics of Sundanese Leadership in History Novel of Mantri Jero by $R$. Memed Sastrahadiprawira}

Abstract: This research is motivated by the assumption that the Sundanese leadership is still weak, whereas in history recorded the names of great Sundanese leaders and can be used as example for others, such as Prabu Wangi, Niskala Wastu Kancana, and Sri Baduga Maharaja. Likewise in works of fiction, one of which is the main character in the historical novel Mantri Jero. This study aims to analyze and describe: 1) the story structure of the historical novel Mantri Jero, 2) the characteristics of Sundanese leadership in the historical novel Mantri Jero, and 3) the value of ethnopedagogy in the historical novel Mantri Jero by R. Memed Sastrahadiprawira. The data source of this research is the historical novel Mantri Jero by R. Memed Sastrahadiprawira. The methods and techniques used in this research are descriptive methods, literature review techniques, and documentary studies, while the way to analyze them is using a qualitative approach. The instrument used was divided into two, namely the instrument for collecting data (checklist of source books) and the instrument for processing data (data cards). The results of this study indicate that the historical novel Mantri Jero has a complete story structure, good Sundanese leadership characteristics, and ethnopedagogic values grouped from the characteristics of good Sundanese leadership.

Keywords: ethnopedagogy; leadership character; Mantri Jero; structure 


\section{PENDAHULUAN}

Ada anggapan bahwa kepemimpinan orang Sunda kurang dikenal dan ada dalam peringkat bawah, jika dibandingkan dengan kepemimpinan etnis lain, misalnya Jawa, padahal dalam sejarah sudah dicatat beberapa nama pemimpin Sunda yang dijadikan panutan, seperti Prabu Wangi, Niskala Wastu Kancana, dan Sri Baduga Maharaja (Isnendes, dkk, 2019, hlm. 79). Berdasarkan pandangan tersebut, tentu saja kepemimpinan Sunda zaman dahulu bisa dijadikan contoh untuk pemimpin pada zaman sekarang. Selain pemimpin Sunda yang telah disebutkan sebelumnya, ada juga pemimpin imajiner dalam karya fiksi yang bisa dijadikan contoh dan juga cerminan masyarakat, yaitu Raden Yogaswara, tokoh utama dalam novel sejarah Mantri Jero karya R. Memed Sastrahadiprawira.

Novel sejarah merupakan novel yang berkaitan dengan sejarah. Dalam novel sejarah Mantri Jero karya R. Memed Sastrahadiprawira terdapat nilai-nilai yang bisa dijadikan contoh dan juga cerminan untuk pemimpin zaman sekarang. Nilainilai kepemimpinan tersebut bisa diteliti dari segi karakteristik dan tata kramanya. Untuk menganalisis hal tersebut, bisa dengan cara dibaca, diteliti, dari mulai isinya, strukturnya, dan juga nilai-nilai yang terdapat dalam novelnya. Teori yang digunakan untuk menganalisisnya, bisa menggunakan pendekatan struktural. Menurut Koswara (2013, hlm. 13), struktur diartikan sebagai suatu hubungan yang tetap antara kelompok-kelompok, gejala, atau unsur elemen yang dilakukan oleh peneliti dari hasil penelitiannya. Selain itu, Isnendes, dkk (2018, hlm. 74) menyatakan bahwa strukturalisme yaitu pendekatan yang diterapkan pada karya sastra yang mempunyai sifat otonom. Artinya, salah satu cara untuk memahami dan menginterpretasi suatu karya sastra yang mempunyai struktur yang lengkap. Pendekatan ini juga bisa digunakan dalam karya sastra novel atau roman. Stanton (2012) membagi unsur pembentuk novel mejadi tiga bagian, yaitu tema, fakta cerita (alur, tokoh atau penokohan, dan latar), dan sarana sastra (sudut pandang, gaya bahasa, suasana, simbol-simbol, imaji, dan judul).

Selain menggunakan pendekatan struktural, untuk menganalisis nilai-nilai yang terkandung dalam novel sejarah Mantri Jero, digunakan pendekatan etnopedagogi, karena dalam novel tersebut terdapat nilai-nilai pendidikan yang bisa dijadikan contoh dan cerminan. Menurut Alwasilah, dkk (2009, kc. 50) etnopedagogi merupakan praktik pendidikan berdasarkan kearifan lokal dalam beberapa bidang, seperti pengobatan, seni bela diri, lingkungan hidup, pertanian, ekonomi, pemerintahan, sistem penangggalan, dan lainlain. Etnopedagogi kesundaan awalnya didasarkan pada keunggulan manusia secara paripurna atau segala bisa (jalma апи masagi). Suherman (2018, hlm. 109) menyebutkan bahwa manusia paripurna (jalma nu masagi) memiliki keseimbangan antara aspek jasmani dan rohani. Tubuhnya sehat jiwanya kuat. Manusia yang benar dalam bernalar, baik akhlaknya serta elok perilakunya. Ia adalah manusia manggapulia, insan kamil, atau dalam terminologi pembangunan nasional disebut sebagai manusia seutuhnya. Selain itu, jalma masagi juga disebut sebagai manusia yang berpengetahuan atau serba tahu serta serba bisa (Satjadibrata dalam Suherman, 2018, hlm. 109). Oleh sebab itu, Hidayat Suryalaga dalam Sudaryat (2015, hlm. 124) mengorientasikan etnopedagogi Sunda dengan sebutan Catur Jati Diri Insan selaku manusia unggul (MAUNG), yaitu pengkuh agamana (spiritual quotient), luhung élmuna (intelectual quotient), jembar budayana (emotional quotient), dan rancagé gawéna (actional quotient). Pedoman yang dijadikan dasar dalam mengukur karakteristik kepemimpinannya, yaitu berdasarkan pada naskah Sunda kuno Sanghyang Siksa Kandang Karesian yang selesai ditulis pada tahun 1518 M. Dalam naskah tersebut terdapat parigeuing, dasa pasanta, pangimbuhning twah, dan opat panyaraman untuk pemimpin dan kepemimpinan (Danasasmita, dkk, 1987). 
Tulisan-tulisan yang mendukung dalam penelitian ini, di antaranya "Nilainilai Kepemimpinan dalam Novel Tjarita Mantri Djero" dan "Otentisitas Kepemimpinan Masyarakat Sunda: Model Pendidikan Karakter Pemimpin dalam Tjarita Mantri Djero" yang ditulis oleh Karim Suryadi pada tahun (2013) dan (2014), lalu dibukukan dalam sebuah buku yang berjudul Pendidikan Karakter dalam Budaya Sunda dan Jepang sebuah Kajian Perbandingan yang terbit pada tahun (2015). Selain itu, ada juga dalam kolom surat kabar Pikiran Rakyat yang berjudul "Pohon Kepemimpinan" (2017) karya Karim Suryadi dan dalam majalah mingguan Manglé yang berjudul "Ijtihad" (2013) karya Karim Suryadi, selanjutnya ada lagi tulisan yang berjudul "Nasihat Mantri Jero" yang ada dalam buku Ménak Senayan karya Karim Suryadi (2017).

Selain itu, ada beberapa penelitian yang telah dilaksanakan sebelumnya, yaitu penelitian yang dilaksanakan oleh Isnendes (2019) yang berjudul "Tata krama Kepemimpinan Sunda dalam Novel Sejarah Tanjeur Na Juritan Jaya di Buana". Hasil dari penelitian ini terdapat karakter pemimpin yang bagus, yang ada dalam diri tokoh utamanya. Selain itu, ada lagi penelitian yang dilaksanakan oleh Hidayat (2008) tentang "Citra Kepemimpinan dalam Sastra Lama: Hikayat Sri Rama dan Wawacan Babad Timbanganten". Dalam penelitian tersebut terdapat citra kepemimpinan dalam Hikayat Sri Rama dan Wawacan Babad Timbanganten yang berhubungan erat dengan model kepemimpinan pada zaman sekarang. Seterusnya, penelitian yang dilaksanakan oleh Edah (2004) tentang "Unsur Étika anu Nyampak dina Novel Mantri Jero pikeun Bahan Pangajaran Sastra di SLTP". Hasil dari penelitian tersebut terdapat unsur-unsur etika yang cocok untuk dijadikan bahan pembelajaran sastra di SLTP. Selanjutnya, penelitian yang dilaksanakan oleh Awaludin (1997) tentang "Karakteristik Kapamingpinan Tokoh Carita dina Novel Sunda". Hasil dari penelitian tersebut, ter- identifikasi adanya karakter kepemimpinan yang bagus dari tiga novel Sunda dan bisa dijadikan contoh untuk para pemimpin.

Sampai sekarang, terdapat beberapa penelitian yang sejenis dengan penelitian yang dilaksanakan. Di antaranya, penelitian yang dilaksanakan oleh Retty Isnendes (2019). Selanjutnya, penelitian yang dilaksanakan oleh Asep Rahmat Hidayat (2008). Lalu, penelitian yang dilaksanakan oleh Eli Cucu Yulia Edah (2004), dan penelitian yang dilaksanakan oleh Dodi Awaludin (1997).

Berdasarkan penelitian yang telah dilaksanakan sebelumnya, teori-teori yang dibahas, dan permasalahan-permasalahan yang dinalisis dalam penelitian ini, menunjukkan adanya persamaan dan perbedaan. Persamaannya, sama-sama meneliti novel sejarah Mantri Jero karya R. Memed Sastrahadiprawira dengan penelitian yang dilaksanakan oleh Awaludin (1997) dan Edah (2004). Hal yang membedakannya, beda objek penelitian dengan penelitian yang dilaksanakan oleh Hidayat (2008) dan Isnendes (2019). Selain itu, beda kajian teori yang digunakan dengan penelitian yang dilaksanakan oleh Awaludin (1997), Edah (2004), Hidayat (2008), dan Isnendes (2019). Dengan demikian, posisi peneliti dalam penelitian ini menjadi yang pertama melaksanakan penelitian tentang struktur, kepemimpinan, dan etnopedagogi dalam novel sejarah Mantri Jero karya R. Memed Sastrahadiprawira.

Tujuan dari penelitian ini, yaitu untuk mengetahui karakteristik kepemimpinan Sunda dalam novel sejarah Mantri Jero karya R. Memed Sastrahadiprawira. Selain itu, penelitian ini juga diharapkan dapat menambah wawasan pengetahuan yang berkaitan dengan kesusastraan dan etnopedagogi, khususnya tentang karakteristik kepemimpinan Sunda, sebab efek dari penelitian ini bisa menambah pengetahuan tentang kepemimpinan yang bagus, berdasarkan karakteristik kepemimpinan Sunda yang ada dalam tokoh Raden Yogaswara, selaku tokoh utama dalam 
novel sejarah Mantri Jero karya R. Memed Sastrahadiprawira.

\section{METODE}

Metode dan teknik yang dipakai dalam penelitian ini, yaitu metode deskriptif analisis, teknik telaah pustaka, dan studi dokumentasi, menggunakan pendekatan kualitatif. Arikunto (2013, hlm. 3) mengemukakan bahwa metode deskriptif analisis bertujuan untuk meneliti keadaan, kondisi, atau hal-hal lain yang telah disebutkan, dan hasilnya ditulis dalam bentuk laporan penelitian.

Sumber data yang digunakan yaitu novel sejarah Mantri Jero karya R. Memed Sastrahadiprawira cetakan kedua Balai Pustaka, Jakarta, 160 halaman.

Instrumen yang digunakan yaitu kartu data. Kartu ini memaparkan data dalam bentuk kutipan-kutipan cerita yang ada dalam novel sejarah Mantri Jero karya R. Memed Sastrahadiprawira, ke dalam indikator-indikator yang akan dianalisis strukturnya, karakteristik kepemimpinannya, dan nilai etnopedagoginya.

Langkah-langkah yang dilakukan oleh peneliti, yaitu 1) persiapan, peneliti merumuskan masalah dan membuat instrumen penelitian; 2) mengumpulkan data, dengan cara teknik telaah pustaka dan studi dokumentasi; 3) mengolah data, menganalisis, dan menafsirkan data; 4) membuat simpulan, 5) menyusun laporan penelitian.

\section{HASIL DAN PEMBAHASAN}

Berdasarkan penelitian yang telah dilaksanakan, terdapat struktur cerita yang lengkap, begitu pun karakter kepemimpinan Sunda dan nilai etnopedagogi dalam novel sejarah Mantri Jero karya R. Memed Sastrahadiprawira.

Novel ini menceritakan tentang Raden Yogaswara atau biasa disebut Mantri Jero. Yogaswara merupakan keturunan menak pada zaman dulu, tapi Yogaswara tidak mengetahui hal tersebut. Karena Yogaswara pekerja keras dan teguh pendirian untuk menjadi menak, dia berusaha dan belajar semaksimal mungkin. Dimulai dari belajar keagamaan di pesantren Janggala, melaksanakan perjalanan ke $d a$ yeuh, menjadi asisten menak, hingga akhirnya Yogaswara diangkat menjadi pemimpin yang sangat dihormati oleh masyarakatnya.

\section{Struktur Cerita Novel Sejarah Mantri Jero}

Teori yang digunakan untuk menganalisis struktur novel sejarah Mantri Jero, yaitu teori struktural Robert Stanton, yang membagi struktur pembentuk karya sastra menjadi tiga bagian, yaitu tema, fakta cerita (alur/plot, tokoh, dan latar), dan sarana sastra (judul, sudut pandang, dan gaya bahasa) (Stanton dalam Isnendes, dkk, 2018, hlm. 94). Selain itu, Isnendes, dkk (2018, hlm. 93-95) juga mengemukakan bahwa setiap unsur karya sastra mempunyai arti dan saling berhubungan dengan makna yang berbeda-beda dalam setiap strukturnya. Dalam novel ini terdapat struktur cerita yang lengkap, dari mulai tema, fakta cerita, dan sarana sastranya.

\section{Tema}

Tema yang diangkat dalam novel ini yaitu sosial-kepemimpinan, yang menceritakan tentang proses pendidikan kepemimpinan Raden Yogaswara untuk dipersiapkan menjadi Mantri Jero dalam keadaan konflik politik padaleman Nagara Tengah yang ada di bawah kekuasaan Mataram. Hal tersebut dapat terlihat dari beberapa permasalahan yang ada dalam novel, yaitu 1) politik negara, 2) pendidikan dan kepemimpinan, 3) dasar agama memengaruhi kepemimpinan, 4) karakter menjadi fokus utama dalam diri pemimpin, 5) suksesi kepemimpinan Raden Yogaswara, dan 6) cinta Yogaswara dan Nyi Halimah. Setelah dianalisis, permasalahan-permasalahan tersebut dapat terlihat dari proses perjalanan Raden Yogaswara, yang awalnya hanya rakyat biasa, hingga akhirnya menjadi Mantri Jero di padaleman Nagara Tengah. 


\section{Fakta Cerita}

Fakta cerita yang terdapat dalam novel ini, yaitu alur/plot, tokoh, dan latar.

\section{Alur/plot}

Alur/plot dalam novel ini dianalisis dari 33 bagian/episode. Seperti yang telah diketahui, bahwa alur/plot merupakan rangkaian kejadian yang disusun secara logis dan kronologis. Dalam setiap episode dibagi menjadi beberapa peristiwa atau kejadian. Seterusnya, dalam setiap kejadiannya dianalisis, sehingga ditemukan alur/plot yang menggerakan cerita, yaitu alur maju dari awal sampai akhir. Untuk lebih jelasnya bisa dilihat dalam tabel 1 .

Tabel 1. Skema Alur Novel Sejarah Mantri Jero

\begin{tabular}{|c|c|c|c|}
\hline No. & Alur & Isi & Episode \\
\hline 1. & Situation & $\begin{array}{l}\text { Pada tahap ini, pengarang hanya memperkenalkan latar } \\
\text { belakang kehidupan tokoh utama, yaitu Raden Yogaswara. } \\
\text { Selain itu, pada tahap ini juga dijelaskan kehidupan sehari-hari } \\
\text { tokoh utama beserta keluarganya yang berprofesi sebagai petani. }\end{array}$ & $(1-5)$ \\
\hline 2. & $\begin{array}{l}\text { Generating } \\
\text { Circumstances }\end{array}$ & $\begin{array}{l}\text { Pada tahap ini mulai ada pergerakan cerita, pengarang sudah } \\
\text { mulai menggerakan cerita melalui diri tokoh utama. Dalam } \\
\text { tahap ini diceritakan bahwa tokoh utama novel sejarah Mantri } \\
\text { Jero, yaitu Raden Yogaswara mempunyai keinginan untuk } \\
\text { menjadi menak. Dengan keinginannya tersebut, Yogaswara } \\
\text { sangat didukung oleh ayahnya, tapi sebelumnya diberikan } \\
\text { nasihat terlebih dahulu, agar mengikuti pembelajaran agama di } \\
\text { pesantren Janggala. Seterusnya, baru diperbolehkan untuk pergi } \\
\text { ke dayeuh Nagara Tengah. }\end{array}$ & (6-12.D) \\
\hline 3. & Rising Action & $\begin{array}{l}\text { Dalam tahap ini cerita sudah mulai memuncak. Hal yang } \\
\text { menyebabkannya, yaitu ketika Raden Yogaswara diberikan } \\
\text { kepercayaan oleh Kangjeng Dalem Nagara Tengah untuk } \\
\text { menjadi Mantri Jero. Hal tersebut menyebabkan orang-orang di } \\
\text { sekelilingnya menjadi iri, salah satunya yaitu Mas Anggataruna. }\end{array}$ & (12.E-16.A) \\
\hline 4. & Climax & $\begin{array}{l}\text { Dalam tahap ini cerita sudah mencapai puncaknya atau bisa } \\
\text { disebut klimaks. Klimaks dalam novel ini terbagi menjadi } \\
\text { empat, yaitu 1) ketika Yogaswara kalah perang oleh Mataram } \\
\text { dan dadanya terkena tumbak, 2) ketika Nagara Tengah diserang } \\
\text { oleh Mataram, 3) ketika Yogaswara difitnah selingkuh dengan } \\
\text { Nyi Ratnawulan, dan 4) ketika Yogaswara diasingkan dan mau } \\
\text { dibunuh. Dari keempat tahapan klimaks tersebut. Klimaks } \\
\text { utama dalam novel ini, yaitu ketika Yogaswara difitnah seling- } \\
\text { kuh bersama Nyi Ratnawulan, karena tahap tersebut membuat } \\
\text { Kangjeng Dalem marah dan munculnya denoument. }\end{array}$ & (16.B-27.C) \\
\hline 5. & Denoument & $\begin{array}{l}\text { Tahap ini merupakan tahap akhir dari cerita. Biasanya disebut } \\
\text { tahap penyelesaian dari semua permasalahan. Tahap ini dimulai } \\
\text { ketika Ki Bulus menjemput ibu dan ayahnya Yogaswara, } \\
\text { seterusnya Yogaswara menjalani hukuman adat, dan Mas Ang- } \\
\text { gataruna mendapat hukuman diusir dari wilayah Nagara Tengah. }\end{array}$ & (28.A-33.G) \\
\hline
\end{tabular}

\section{Tokoh/penokohan}

Secara umum, tokoh dalam novel ini terbagi menjadi dua, yaitu tokoh utama dan tokoh tambahan. Seperti yang dikemukakan oleh Nurgiyantoro (2013, hlm. 176), bahwa tokoh mempunyai peranan yang sangat penting dalam suatu cerita, sebab bisa menghidupkan suasana cerita. Tokoh utama dalam novel ini yaitu Raden Yogaswara, sebab tokoh tersebut selalu muncul dari awal cerita sampai akhir cerita. Seterusnya, yang termasuk tokoh tambahan dalam novel ini terbagi menjadi dua, yaitu tokoh tambahan yang mengiringi tokoh utama dan tokoh yang benar-benar tokoh tambahan. Tokoh yang termasuk tokoh tambahan yang mengiringi tokoh utama yaitu Kangjeng Dalem, juragan Patih, Raden Wirautama, ibunya Yogaswara, Kiai Abdul Mugni, Mas Anggataruna, dan Nyi 
Halimah, sedangkan tokoh yang benarbenar tokoh tambahan, di antaranya Tritrusta, Ki Sembada, Ki Dora, Madasim, Ki Bulus, Ma Awinah, Ki Sura, Dalem Kawasen, Kaliwon, Sultan Mataram, dan lainlain.

Dalam novel ini, pengarang mendeskripsikan watak atau sifat para tokohnya secara langsung. Hal tersebut dapat terlihat dari beberapa tokoh yang tadi telah disebutkan, yaitu Raden Yogaswara, Raden Wirautama, ibunya Yogaswara, Kangjeng Dalem, juragan Patih, Kiai Abdul Mugni, dan Nyi Halimah mempunyai sifat atau watak tokoh yang baik (protagonis), sedangkan Mas Anggataruna dan Kaliwon mempunyai sifat jahat dan suka iri dengki kepada orang lain (antagonis).

\section{Latar}

Latar yang terdapat dalam novel ini terdiri dari latar tempat, waktu, dan sosial. Oleh sebab itu bisa disebutkan bahwa seluruh latar terdapat dalam novel ini. Seperti yang dikemukakan oleh Abrams dalam Nurgiyantoro (2013, hlm. 217), bahwa latar atau setting biasanya menunjukkan pada tempat, hubungan waktu, dan lingkungan sosial.

Secara umum, latar tempat yang terdapat dalam novel ini terdiri dari latar tempat padaleman, pilemburan, dan pasantrén. Untuk lebih jelasnya bisa dilihat dari kutipan berikut ini.

Saur Den Jogaswara: "Lain tegalan, meureun ieu teh nu disebut alun-alun tea, tuh geuning beulah ti kidul aja imah gede, meureun eta teh padaleman tea." (kc. 38).

(Kata Den Yogaswara: "Bukan tegalan, mungkin itu yang disebut alun-alun, tuh lihat sebelah selatan ada rumah besar, mungkin itu yang disebut padaleman.") (hlm. 38).

Beh andjeunna ningali sampalan ngeblak, di sisina aja lembur leutik, imahna oge meureun aja tilu suhunan mah. Di sampalan teh rendang pirang-pirang munding djeung domba, keur njaratuan. "Tuh urang njimpang heula ka lembur," saur Mantri Djero, "urang neangan dahareun heula!" (kc. 27). (Dia menoleh ke arah tempat yang luas, di pinggirnya ada lembur kecil, rumahnya hanya ada tiga. Di tempat yang luas tersebut banyak kerbau dan domba, sedang makan. "Tuh kita datang dulu ke lembur," kata Mantri Jero, "kita mencari makan dulu!") (hlm. 27).

Henteu katjaritakeun di djalanna, kakotjapkeun Raden Jogaswara geus tjunduk ka nu didjugdjug, datang ka nu diteang, ka pasantren Djanggala, tempat Kiai Abdul Mugni ngawuruk elmu, mitutur sabda rahaju, midemit sabda sadjati (kc. 22).

(Tidak diceritakan di jalannya, Raden Yogaswara sudah sampai pada tujuan, yaitu pesantren Janggala, tempat Kiai Abdul Mugni memberikan pelajaran keagamaan) (hlm. 22).

Dalam kutipan sebelumnya terdapat latar yang menunjukkan tempat, seperti yang sudah disebutkan yaitu padaleman, pilemburan, dan pasantrén. Seterusnya, dalam novel ini juga terdapat latar waktu.

Latar waktu yang terdapat dalam novel ini di antaranya 1) rebun-rebun, 2) wanci pecat sawed, 3) pasosoré, 4) poé senén, 5) heuleut saminggu, dan lain-lain, tapi setelah dianalisis, latar waktu yang tergambar dalam novel ini menunjukkan abad ke-17, yaitu waktu tatar Sunda dijajah oleh Mataram.

Latar waktu dalam novel ini juga berkaitan dengan latar sosial, hal tersebut dapat terlihat dari adanya stratifikasi sosial atau tingkatan sosial yang tergambar dalam novel, seperti adanya sebutan: 1) Mantri Jero, 2) Kangjeng Dalem, 3) Kiai, 4) rahayat, dan lain-lain. Dengan adanya hal tersebut akhirnya bisa dikelompokkan bahwa tingkatan sosial dalam novel ini terdiri dari: 1) tingkatan menak atau pamongpraja, 2) tingkatan menengah atau pesantren, 3) tingkatan cacah atau rakyat. Hal tersebut terbukti dari adanya namanama yang menggunakan awalan Radén, Kangjeng Dalem, Juragan Patih, Jaksa, Kiai, $M a, B i, K i$, dan lain-lain.

\section{Sarana Sastra}

Sarana sastra dalam novel ini terbagi menjadi tiga, yaitu judul, sudut pandang, dan gaya bahasa. 
Judul

Novel yang diteliti ini memiliki judul Mantri Jero. Hal tersebut sesuai dengan isinya yang menceritakan perjalanan Raden Yogaswara dari mulai kanak-kanak sampai menjadi Mantri Jero di padaleman Nagara Tengah. Seterusnya judul ini juga mempunyai beberapa tingkatan makna, yaitu 1) jadi orang harus sabar, seperti halnya Yogaswara, dalam menjalani kehidupannya yang penuh dengan kesabaran; 2) untuk menjadi pemimpin harus dipersiapkan segala sesuatunya, seperti halnya Yogaswara, sebelum menjadi Mentri Jero pernah mengalami proses kehidupan yang sangat panjang dan dipersiapkan segala sesuatunya, mulai dari menjadi rakyat biasa yang suka diajari membaca dan menulis oleh ayahnya, petani, santri, tukang mengurus kuda, tukang epok, dan akhirnya diangkat menjadi Mantri Jero; 3) awal akhir kejahatan akan terbongkar, seperti halnya Anggataruna yang mendapat hukuman dari Kangjeng Dalem karena mempunyai sifat yang jahat, licik, dan serakah.

\section{Sudut Pandang}

Dalam novel ini pengarang memusatkan sudut pandang agar cerita yang ditulisnya sampai kepada pembaca. Sudut pandang yang digunakan yaitu sudut pandang orang ketiga-tidak terbatas. Hal tersebut dapat terlihat dari cara pengarang menyampaikan ceritanya, lebih bebas, serba tahu, dan tidak memusat pada diri pengarangnya saja, tetapi lebih luas, dan setiap kejadiannya lebih bebas diceritakan. Sebagaimana yang dikemukakan oleh Stanton (2012, hlm. 53), bahwa sudut pandang orang ketiga-tidak terbatas, pengarang mengendalikan semua karakter dan memosisikan dirinya menjadi orang ketiga. Seterusnya, pengarang juga bisa membuat beberapa karakter untuk melihat, mendengar, dan berpikir, walaupun tidak ada karakter yang diceritakannya. Hal tersebut sesuai dengan model penceritaan dalam novel Mantri Jero. Oleh sebab itu, sudut pandang yang digunakannya, yaitu orang ketiga-tidak terbatas.
Selain sudut pandang, dalam novel ini juga terdapat gaya bahasa atau style yang digunakan oleh pengarang, agar ceritanya sampai kepada pembaca.

\section{Gaya Bahasa}

Gaya bahasa yang digunakan dalam novel ini bisa dikelompokkan berdasarkan cara pengarang menyampaikan pembicaraannya, atau ungkapan kalimat setiap tokohnya. Gaya bahasa tersebut terdapat dalam empat ragam bahasa, yaitu 1) ragam bahasa menak Sunda, 2) ragam bahasa menak Jawa, 3) ragam bahasa Abdi-abdi Dalem, dan 4) ragam bahasa cacah atau rakyat, tapi secara umum gaya bahasa yang digunakan dalam novel ini yaitu gaya bahasa litotes (ngasor), gaya bahasa pleonasme (kadalon), gaya bahasa lalandian, gaya bahasa alegori (silib), gaya bahasa periprase (ébrehan), dan gaya bahasa hiperbola (rarahulan). Seperti yang dikemukakan oleh Iskandarwassid (2019, hlm. 66), bahwa gaya bahasa merupakan corak ekspresi bahasa baik dalam bentuk puisi maupun dalam bentuk prosa; gaya bahasa juga merupakan suatu cara yang digunakan oleh pengarang untuk menyampaikan ucapan, biasanya sifat dalam gaya bahasa tersebut dapat terlihat melalui diksi, ungkapan kalimat, macam-macam perbandingan dan penekanan arti, pola wirahma, dan ciri-ciri bentuk lainnya, atau rakitan bahasa.

\section{Karakteristik Kepemimpinan Sunda dalam Novel Sejarah Mantri Jero}

Karakteristik kepemimpinan Sunda yang digunakan untuk menganalisis novel ini yaitu karakteristik kepemimpinan Sunda berdasarkan tata krama kepemimpinan Sunda yang ada dalam naskah Sunda kuno Sanghyang Siksa Kandang Karesian, yang terdiri dari parigeuing, dasa pasanta, pangimbuhning twah, dan opat panyaraman untuk pemimpin dan kepemimpinan (Danasasmita, dkk, 1987).

\section{Parigeuing}

Parigeuing mempunyai arti bisa memerintah. Dalam novel ini terdapat bukti 
bahwa Yogaswara dapat memerintah dengan baik. Hal tersebut terlihat ketika Yogaswara memimpin perang melawan Mataram. Selain itu, ketika Yogaswara memimpin perjalanan ke Pasir Uncal, seterusnya ketika Yogaswara menjalankan amanat dari Kangjeng Dalem untuk mengurus padaleman, saat Kangjeng Dalem pergi ke Mataram untuk mengirimkan upeti. Berdasarkan hal tersebut, maka dapat terlihat bahwa Yogaswara bisa memerintah dengan baik.

\section{Dasa Pasanta}

Menurut nenek moyang Sunda zaman dulu, untuk menjalankan parigeuing tentu ada tata caranya. Hal tersebut disebut dasa pasanta. Menurut Suryalaga (1994, hlm. 113), dasa pasanta disebut penentram atau cara memerintah dengan baik, agar yang diperintah merasa semangat untuk bekerja, sebab dirinya merasa menjadi bagian dari diri pemimpinnya. Yang termasuk dasa pasanta, yaitu guna (mengerti perintah), ramah (ramah), hook (kagum), pesok (bangga), asih (rasa sayang), karunia/karunya (rasa kasihan karena sayang), mukpruk (merayu), ngulas (memberi komentar dengan cara yang baik), nyecep (menentramkan), dan ngala angen (menarik simpati). Setelah dianalisis, dalam diri Yogaswara terdapat karakter dasa pasanta, hal tersebut dapat terlihat dari kepribadiannya, tingkah lakunya, lalu dikagumi oleh banyak orang, bisa memberi komentar dengan cara yang baik kepada bawahannya, menentramkan, mempunyai rasa kasih sayang kepada orang-orang di sekelilingnya, dan disukai banyak orang. Buktinya, Yogaswara sampai diangkat menjadi Mantri Jero oleh Kangjeng Dalem Nagara Tengah, yang asalnya hanya seorang pengurus kuda di padaleman. Hal tersebut menunjukkan bahwa Yogaswara mempunyai karakter pemimpin yang bagus.

\section{Pangimbuhning Twah}

Pangimbuhning twah yaitu karakteristik atau tata krama pelengkap penambah pamor. Jumlah tata krama ini ada 12, yaitu emét (hemat), imeut (teliti), rajeun (rajin), leukeun (tekun), pakapradana (berani), morogol-rogol (ingin maju), purusa ning sa (patriotik), widagda (bijaksana), gapitan (berani berkorban), karawaléya (dermawan), cangcingan (cekatan), dan langsitan (terampil) (Suryalaga, 1994, hlm. 52-54). Setelah dianalisis, dalam diri Yogaswara terdapat karakter pangimbuhning twah. Hal tersebut dapat dilihat dari rangkaian ceritanya, bahwa segala sesuatu yang dilakukan oleh Yogaswara dapat menimbulkan kebanggaan pada orang-orang yang melihatnya. Artinya, dalam diri Yogaswara sudah terdapat karakter ini. Selain itu, pengarang juga menggambarkan dengan jelas sipat-sipat yang dimiliki oleh Yogaswara itu benar-benar bagus dan menimbulkan daya tarik pada pembacanya.

\section{Opat Panyaraman}

Dalam naskah Sanghyang Siksa Kandang Karesian (1518 M) terdapat empat hal yang dilarang atau hal yang tidak boleh dilakukan oleh orang Sunda, khususnya seorang pemimpin, hal tersebut yaitu babarian, pundungan, humandeuar, dan kukulutus (Suryalaga, 1994, hlm. 5455), tapi dalam novel sejarah Mantri Jero karya R. Memed Sastrahadiprawira hanya ditemukan satu sipat saja, yaitu humandeuar. Kebiasaan orang yang suka humandeuar sangat jelek sekali dan sangat dilarang. Orang yang mempunyai sipat ini menandakan lemah jiwanya dan kecil semangatnya, tidak berani menghadapi tantangan dalam kehidupannya. Kebiasaannya hanya marah-marah (Suryalaga, 1994, hlm. 55). Untuk lebih jelasnya bisa dilihat dalam kutipan berikut ini.

\footnotetext{
Jogaswara ngadangu kasauran ramana kitu teh semu teu milu bungah, piundjukna: "Da eta matjul teh, nja panas, nja jareblog!” (kc. 5).

(Ketika Yogaswara mendengar ayahnya berbicara seperti itu, dia merasa tidak suka, ucapnya: "Macul itu panas dan kotor!") (hlm. $5)$.
} 
Dalam kutipan di atas dapat dilihat, walaupun Yogaswara mempunyai sipat humandeuar, tapi hal tersebut tidak disebut jelek, karena ketika Yogaswara berbicara seperti itu masih dalam usia kanak-kanak, dan belum dewasa. Selain itu, arti dari Yo- gaswara berbicara seperti itu dapat disimpulkan, bahwa dalam diri Yogaswara ada rasa ingin maju.

Jadi setelah dianalisis, karakteristik kepemimpinan Sunda yang terdapat dalam diri Yogaswara dapat dilihat dalam tabel 2.

Tabel 2. Karakteristik Kepemimpinan Sunda dalam Novel Sejarah Mantri Jero

\begin{tabular}{|c|c|c|c|}
\hline \multirow[t]{2}{*}{ No. } & \multirow[t]{2}{*}{ Karakteristik Kepemimpinan Sunda } & \multicolumn{2}{|c|}{ Hasil Analisis dan Penelitian } \\
\hline & & Ditemukan & Tidak Ditemukan \\
\hline 1. & Parigeuing & $\checkmark$ & - \\
\hline \multirow[t]{11}{*}{2.} & Dasa Pasanta & & \\
\hline & a. Guna & $\checkmark$ & - \\
\hline & b. Ramah & $\checkmark$ & - \\
\hline & c. Hook & $\checkmark$ & - \\
\hline & d. Pesok & $\checkmark$ & - \\
\hline & e. Asih & $\checkmark$ & - \\
\hline & f. Karunia/Karunya & $\checkmark$ & - \\
\hline & g. Mukpruk & $\checkmark$ & - \\
\hline & h. Ngulas & $\checkmark$ & - \\
\hline & i. $\quad$ Nyecep & $\checkmark$ & - \\
\hline & j. Ngala Angen & $\checkmark$ & - \\
\hline \multirow[t]{13}{*}{3.} & Pangimbuhning Twah & & \\
\hline & a. Emét & $\checkmark$ & - \\
\hline & b. Imeut & $\checkmark$ & - \\
\hline & c. Rajeun & $\checkmark$ & - \\
\hline & d. Leukeun & $\checkmark$ & - \\
\hline & e. Pakapradana & $\checkmark$ & - \\
\hline & f. Morogol-rogol & $\checkmark$ & - \\
\hline & g. Purusa ning sa & $\checkmark$ & - \\
\hline & h. Widagda & $\checkmark$ & - \\
\hline & i. Gapitan & $\checkmark$ & - \\
\hline & j. Karawaléya & $\checkmark$ & - \\
\hline & k. Cangcingan & $\checkmark$ & - \\
\hline & l. Langsitan & $\checkmark$ & - \\
\hline \multirow[t]{5}{*}{4.} & Opat Panyaraman & & \\
\hline & a. Babarian & - & $\checkmark$ \\
\hline & b. Pundungan & - & $\checkmark$ \\
\hline & c. Humandeuar & $\checkmark$ & - \\
\hline & d. Kukulutus & - & $\checkmark$ \\
\hline
\end{tabular}

\section{Nilai Etnopedagogi dalam Novel Sejarah Mantri Jero}

Hidayat Suryalaga dalam Sudaryat (2015, hlm. 124) mengorientasikan etnopedagogi Sunda dengan sebutan Catur Jati Diri Insan selaku manusia unggul (MAUNG), yaitu pengkuh agamana (spiritual quotient), luhung élmuna (intelectual quotient), jembar budayana (emotional quotient), dan rancagé gawéna (actional quotient). Dalam novel ini terdapat nilai etnopedagogi Sunda yang telah dikelompokkan dari karakteristik kepemimpinan Sunda.

\section{Pengkuh Agamana (spiritual quotient)}

Nilai etnopedagogi ini mempunyai arti teguh pendirian dan bersungguhsungguh dalam menjalankan syariat-syariat agama. Selain itu, etnopedagogi ini juga berpegang teguh pada moral manusia pada Tuhannya. Setelah dianalisis, karakteristik kepemimpinan Sunda yang termasuk ke dalam nilai etnopedagogi ini, yaitu 1) asih, 2) karunia/karunya, 3) emét, 4) imeut, 5) rajeun, 6) leukeun, 7) morogol-rogol, dan 8) karawaléya. Hal tersebut dapat dilihat dari setiap karakteristiknya, terdapat nilai- 
nilai keagamaan, seperti belajar mengaji Quran dan kitab, dermawan, rajin belajar, dan lain-lain.

\section{Luhung Élmuna (intelectual quotient)}

Nilai etnopedagogi ini berkaitan dengan kecerdasan dalam menyelesaikan permasalahan hidup, menguasai IPTEK, cerdas, serba tahu, dan mempunyai daya saing yang bagus (luhur ku élmu, jembar ku pangabisa, sugih ku pangarti). Biasanya didasarkan pada moral manusia pada alam dan waktu. Setelah dianalisis, karakteristik kepemimpinan Sunda yang termasuk ke dalam nilai etnopedagogi ini, yaitu 1) parigeuing, 2) guna, dan 3) cangcingan. Hal tersebut dapat dilihat dari karakterkarakternya yang membutuhkan kecerdasan secara khusus. Seperti menjadi seorang pemimpin, tentu tidak asal-asalan, tetapi harus memiliki karakter yang bagus dan ilmu pengetahuan yang luas.

\section{Jembar Budayana (emotional quotient)}

Nilai etnopedagogi ini berkaitan dengan kecerdasan emosi, ilmu pengetahuan, arif, bijaksana, mengetahui tentang budaya, serta tidak melupakan jati dirinya sebagai manusia yang mempunyai agama (religius) yang bisa saling menghargai dengan sesama manusia lainnya (multietnis dan multikultur). Hal ini berdasar pada manusia secara pribadi dan manusia lainnya. Setelah dianalisis, karakteristik kepemimpinan Sunda yang termasuk ke dalam etnopedagogi ini, yaitu 1) ramah, 2) nyecep, 3) purusa ning sa, 4) widagda, dan 5) gapitan, sebab dalam karakter-karakter tersebut terdapat nilai-nilai ilmu pengetahuan, budaya, dan tentu bisa saling menghargai dengan sesama manusia di sekelilingnya.

\section{Rancagé Gawéna (actional quotient)}

Nilai etnopedagogi ini berkaitan dengan IQ, EQ, dan SQ, serta harus mempunyai pemikiran yang cepat dalam bekerja, berprestasi, aktif, terampil, dan dapat menyesuaikan dirinya dengan perkembangan zaman (ngindung ka waktu, mibapa ka jaman). Hal tersebut berpegang teguh pada moral manusia dalam merasakan kepuasan lahir dan batinnya. Setelah dianalisis, karakteristik kepemimpinan Sunda yang termasuk ke dalam etnopedagogi ini adalah 1) hook, 2) pesok, 3) mukpruk, 4) ngulas, 5) ngala angen, 6) pakapradana, dan 7) langsitan, sebab karakteristik kepemimpinan tersebut membutuhkan keterampilan secara khusus.

\section{SIMPULAN}

Mantri Jero merupakan novel sejarah yang isinya menceritakan tentang kepemimpinan pada abad ke-17. Tokoh utama yang diceritakan dalam novel ini yaitu Raden Yogaswara. Setelah dianalisis, struktur ceritanya lengkap, dari mulai tema, fakta cerita, dan sarana-sarana sastranya. Tema yang diangkat dalam novel ini yaitu sosial-kepemimpinan, yang menceritakan tentang proses pendidikan kepemimpinan Raden Yogaswara yang dipersiapkan untuk dijadikan Mantri Jero dalam keadaan konflik politik padaleman Nagara Tengah yang ada dalam kekuasaan Mataram. Seterusnya, latar yang terdapat dalam novel ini pun saling berkaitan, dari mulai latar tempatnya, latar waktunya, dan latar sosialnya yang menunjukkan keadaan pada abad ke-17. Selain itu, sarana sastra yang ada dalam novel ini pun sudah memenuhi syarat, dari mulai judulnya yang sesuai dengan isi cerita, gaya bahasa, dan sudut pandang yang menggunakan sudut pandang orang ketiga-tidak terbatas.

Dalam novel ini terdapat karakteristik kepemimpinan Sunda yang ada pada diri Yogaswara selaku tokoh utamanya. Karakter-karakter tersebut yaitu parigeuing, dasa pasanta, pangimbuhning twah, dan opat panyaraman. Seterusnya, hal tersebut bisa dijadikan contoh untuk pemimpin pada zaman sekarang.

Terakhir, dalam novel ini terdapat nilai-nilai etnopedagogi. Secara umum, nilai-nilai etnopedagogi yang terdapat dalam novel ini dihubungkan dengan nilai keagamaan, ilmu pengetahuan, dan budaya. 


\section{UCAPAN TERIMA KASIH}

Penulis mengucapkan terima kasih kepada semua pihak yang telah membantu dalam pembuatan tulisan ini. Semoga dapat bermanfaat, khususnya bagi penulis, umumnya bagi semua pembaca.

\section{CATATAN PENULIS}

Penulis menyatakan bahwa tidak ada konflik kepentingan terkait publikasi artikel ini. Penulis mengkonfirmasi bahwa data dan artikel ini bebas plagiarisme.

\section{PUSTAKA RUJUKAN}

Alwasilah, A. C. dkk. (2009). Etnopedagogi: Landasan Praktek Pendidikan dan Pendidikan Guru. Bandung: Kiblat Buku Utama.

Arikunto, S. (2013). Prosedur Penelitian: Suatu Pendekatan Praktik. Jakarta: Rineka Cipta.

Awaludin, D. (1997). Karakteristik Kapamingpinan Tokoh Carita dina Novel Sunda. (Skripsi). FPBS, Universitas Pendidikan Indonesia.

Danasasmita, S. dkk. (1987). Séwaka Darma, Sanghiyang Siksa Kandang Karesian, Amanat Galunggung: Transkrip dan Terjemahan. Bandung: Bagian Proyek Penelitian dan Pengkajian Kebudayaan Sunda (Sundanologi) Direktorat Jenderal Kebudayaan Departemen Pendidikan dan Kebudayaan.

Edah, E. C. Y. (2004). Unsur Etika anu Nyampak dina Novel Mantri Jero pikeun Bahan Pangajaran Sastra di SLTP. (Skripsi). FPBS, Universitas Pendidikan Indonesia.

Hidayat, A. R. (2008). Citra Kepemimpinan dalam Sastra Lama: Hikayat Sri Rama dan Wawacan Babad Timbanganten. Jurnal Metasastra, Vol. 1, No. 1.

Iskandarwassid. (2019). Kamus Istilah Sastra Sunda. Bandung: Geger Sunten.
Isnendes, C. R. dkk. (2018). Teori Sastra Kontemporer: Formalisme, Strukturalisme, dan Semiotika. Bandung: UPI PRESS.

Isnendes, R. dkk. (2019). Tata krama Kepemimpinan Sunda dalam Novel Sejarah Tanjeur na Juritan Jaya di Buana Karya Yoseph Iskandar. Lokabasa, 10(1), 78.

Koswara, D. (2013). Racikan Sastra. Bandung: JPBD FPBS UPI.

Nurgiyantoro. (2013). Teori Pengkajian Fiksi. Yogyakarta: Gadjah Mada University Press.

Ruhaliah. (Penyunting). (2015). Pendidikan Karakter dalam Budaya Sunda dan Jepang Sebuah Kajian Perbandingan. Bandung: Penelitian Bersama UPI-Nanzan University, Jepang.

Stanton, R. (2012). Teori Fiksi Robert Stanton. Yogyakarta: Pustaka Pelajar.

Sudaryat, Y. (2015). Wawasan Kesundaan. Bandung: JPBD FPBS UPI.

Suherman, A. (2018). Jabar Masagi: Penguatan Karakter Bagi Generasi Milenial Berbasis Kearifan Lokal. Lokabasa, 9(2), 107.

Suryadi, K. (2013). "Ijtihad". Manglé.

Suryadi, K. (2013). Nilai-nilai Kepemimpinan dalam Novel Tjarita Mantri Djero. Dalam Ruhaliah (Penyunting), Pendidikan Karakter dalam Budaya Sunda dan Jepang Sebuah Kajian Perbandingan. Bandung: Penelitian Bersama UPINanzan University, Jepang.

Suryadi, K. (2014). Otentisitas Kepemimpinan dalam Tjarita Mantri Djero: Sebuah Model Pendidikan Karakter Pemimpin. Dalam Ruhaliah (Penyunting), Pendidikan Karakter dalam Budaya Sunda dan Jepang Sebuah Kajian Perbandingan. Bandung: Penelitian Bersama UPI- 
Nanzan University, Jepang.

Suryadi, K. (2017). Menak Senayan: Arsitek Komunikasi Politik Indonesia. Bandung: Pustaka Jaya.
Suryadi, K. (2017). "Pohon Kepemimpinan". Pikiran Rakyat.

Suryalaga, R. H. (1994). Étika jeung Tatakrama. Bandung: Geger Sunten. 